Stawa Grzechnik

Uniwersytet Gdański

\title{
Style komunikacyjne podmiotów edukacji w perspektywie gender. Krytyczna analiza dyskursu ${ }^{1}$
}

\section{Wprowadzenie}

Badanie problematyki języka w użyciu zajmuje nie tylko silną pozycję w obszarze socjologii kultury, ale również znacząco wpływa na obraz i sposób widzenia pedagogiki oraz dyskursywnego funkcjonowania klasy szkolnej. Komunikowanie się jest procesem społecznym nieodłącznie związanym z procesem nauczania, uczenia się uczennic i uczniów oraz konstruowania przez nich wiedzy (Klus-Stańska 2010). Style komunikacyjne nauczycielek oraz nauczycieli ujawniają androcentryzm w postaci genderowych nierówności wpisanych w logikę funkcjonowania pola społecznego, jakim jest klasa szkolna. W niniejszym artykule prezentuję style komunikacyjne urzeczywistniane przez nauczycielki i nauczycieli w interakcjach werbalnych $\mathrm{z}$ uczennicami oraz uczniami. Interakcje komunikacyjne są zhierarchizowane genderowo, co oznacza, że dziewczęta umiejscowione są w innych punktach badanego pola niż chłopcy. Wiąże się to z faktem, że w dyskursywnej przestrzeni klasy szkolnej tworzona jest spolaryzowana genderowo wiedza. Spleciona jest ona z nauczycielską władzą przy współudziale mocy „tradycyjnego” illusio $^{2}$, stanowiącego uprawomocnienie dla stosowanych stylów komunikacyjnych.

Język w użyciu, sytuacje mówienia oraz sposób ich rozumienia przez podmioty edukacji zakorzenione są w strukturze pola społecznego, w tym również subpola ${ }^{3}$, którym jest klasa szkolna. Związek kultury szkoły z kulturą symboliczną jest

\footnotetext{
${ }^{1}$ Prezentowany tekst jest streszczeniem zmodyfikowanego podrozdziału o stylach komunikacyjnych podmiotów edukacji mojej rozprawy doktorskiej Język i gender podmiotów edukacji. Krytyczna analiza dyskursu.

${ }^{2}$ Illusio - praktyczna wiara, dobrze ugruntowane przekonanie o potrzebie akceptacji zastanego porządku społecznego. Stanowi jedną ze znaczących kategorii w teorii społecznej Pierre'a Bourdieu.

${ }^{3}$ Dla określenia „subpola” klasy szkolnej będę używała pojęcia „pole klasy szkolnej”.
} 
odtwarzany poprzez językowe interakcje komunikacyjne. Nauczycielsko-uczniowskie zachowania werbalne pozycjonujące wszystkie elementy pola społecznego $\mathrm{w}$ procesie, jakim jest toczący się codziennie dyskurs podmiotów edukacji w przestrzeni klasy szkolnej, ukazują ich sposoby myślenia, mówienia, postrzegania oraz doświadczania hierarchizacji genderowej. Zwerbalizowany szkolny świat uczennicy oraz ucznia zbudowany z językowych „wytworów” podmiotów, to jest nauczycielek, nauczycieli, uczennic oraz uczniów zaangażowanych w proces nauczania/ uczenia się uwikłany jest w trybie wysokiej złożoności w mechanizmy kultury symbolicznej, algorytmy tworzenia wiedzy, rozumienia nauczycielskiej władzy, habitusów genderowych oraz nadawania znaczeń swojemu umiejscowieniu w polu klasy szkolnej. Porządek owego świata jest zhierarchizowany genderowo i pozycjonuje jednostki według dyrektyw koherentnie oraz komplementarnie skonfigurowanej wszechobecnej władzy, jako dominacji nad poznaniem, wiedzą, (nie)wiedzą, ciałem oraz tworzeniem indywidualnej tożsamości. „Natura” bytu i procesu zarazem, jakim jest hierarchizacja genderowa, ukazana została poprzez sposób użycia języka ukonstytuowany w stylach komunikacyjnych podmiotów edukacji z zastosowaniem teorii społecznej Pierre’a Bourdieu oraz koncepcji władzy i ujarzmiania jednostki Michela Foucaulta.

Język i style komunikacyjne stanowią narzędzia konstytuujące oraz odtwarzające zastany porządek w każdym polu społecznym, w tym również w klasie szkolnej. Bourdieu prezentuje w swych dziełach sposób myślenia o świecie oparty na strukturalizmie konstruktywistycznym, gdzie zwraca szczególną uwagę na systemy symboliczne, jak język oraz istnienie obiektywnych struktur „pulsujących” niezależnie od świadomości i woli aktywnych podmiotów (Bourdieu 1989). Takie podejście przyjęłam w swoim projekcie badawczym, skupiając się nad sposobem wytwarzania różnic genderowych w stylach komunikacyjnych przez podmioty: uczennice, uczniów, nauczycielki i nauczycieli. Autor teorii pola społecznego widzi pole społeczne jako przestrzeń, w której wszelkie działania, praktyki komunikacyjne oraz język, mające miejsce $\mathrm{w}$ analizowanym polu społecznym (klasie szkolnej), odnoszą się do tego konkretnego obszaru świata społecznego. Istotną cechą pola społecznego jest to, że funkcjonuje ono względnie niezależnie od innych mikroświatów (pól) zgodnie z własnym nomos. Wartym podkreślenia jest fakt, że pole społeczne jest wycinkiem ustrukturyzowanej przestrzeni społecznej urzeczywistniającym się zgodnie z własnym porządkiem, który stanowi przestrzeń dla językowego działania jednostek (nauczycielek, nauczycieli, uczennic oraz uczniów). Klasa szkolna stanowi małą wspólnotę sytuacyjną, w której język i style komunikacyjne stanowią kategorie o szczególnym znaczeniu dla rozwoju uczennic i uczniów. Proces uczenia się w i poprzez interakcje komunikacyjne oraz urzeczywistniającą się socjalizację genderową przynosi efekty, które są i będą widoczne oraz odczuwalne w doświadczaniu przez uczennice oraz uczniów szeroko pojętego pola społecznego umiejscowionego poza murami klasy szkolnej. Jednostki pola społecznego: uczennice, uczniowie, nauczycielki i nauczyciele zajmują określone 
pozycje zgodnie z porządkiem hierarchicznym, który urzeczywistnia i utrwala się poprzez praktyki i style komunikacyjne. Wyżej wymienione podmioty funkcjonujące w klasie szkolnej wraz z illusio odtwarzają swoje role w klasie szkolnej zgodnie $\mathrm{z}$ hierarchizacją genderową poprzez codzienny udział i zaangażowanie w utrwalanie stylów komunikacyjnych. Temu procesowi towarzyszy dobrze ugruntowane przekonanie i wiara (illusio) w to, że praktyki i style komunikacyjne są równie dobre co ich skutki. W polu społecznym zhierarchizowanym genderowo dostrzegalna jest dominacja jednych jednostek na drugimi, o której wiele pisze w swojej koncepcji władzy jako dominacji Foucault. Ikonoklasta, za którego uważa się twórcę omawianej koncepcji, postrzega władzę jako sieć relacji oraz stosunków siły, które są nieustannie aktywne. Taką aktywność zauważyć można również w stylach komunikacyjnych analizowanych w ramach moich badań. W sposobie myślenia Foucaulta o władzy postrzeganej jako dominacja nauczyciele i nauczycielki uwikłani są w sieć relacji władzy poprzez „posiadanie” władzy nad poznaniem i wiedzą uczennic oraz uczniów. Zaangażowanie wszystkich jednostek pola klasy szkolnej w relacje władzy urzeczywistnia się w codziennym odtwarzaniu stylów komunikacyjnych.

Język oraz gender to kategorie nieodłącznie powiązane z poznawaniem, świadomością refleksyjną, rozumieniem oraz (nie)porozumieniem manifestującym się w przestrzeni komunikacyjnej badanych podmiotów edukacji. Płeć kulturowa stanowiąca społeczny konstrukt dyskursywno-performatywny to jedno z głównych pojęć w przestrzeni rozumienia rzeczywistości społecznej, a także na płaszczyźnie myślenia o innych aktorkach i aktorach społecznych. Hierarchizacja genderowa w ramach niniejszego projektu badawczego ukazana została poprzez sposób użycia języka ukonstytuowany w relacjach oraz nauczycielsko-uczniowskich stylach komunikacyjnych. Najlepszą metodą wywodzącą się z tradycji etnograficznej, pozwalającą wniknąć w sposób użycia języka i jego uwikłanie w mechanizmy mogące przyczyniać się do zjawiska hierarchizacji genderowej w klasie szkolnej, jest etnografia komunikacji. Przedmiotem analiz są style komunikacyjne zarówno nauczycielek, nauczycieli, jak i uczniów oraz uczennic, zakreślające granice dyskursywnych pozycji wymienionych podmiotów. W ramach sposobów użycia języka badam zarówno nauczycielsko-uczniowskie, uczniowsko-nauczycielskie, jak i uczniowskie (uczennic z uczniami, uczennic z uczennicami oraz uczniów z uczniami) płaszczyzny stylów komunikacyjnych. Jednakże w niniejszym artykule skupiam się głównie na nauczycielsko-uczniowskich stylach komunikacyjnych.

Czytelne linie genderowego podziału (Karwatowska, Szpyra-Kozłowska 2005: 139; Bochno 2009), odtwarzane oraz konstruowane w codzienności klasy szkolnej, umiejscowione są nie tylko w obszarze nieświadomości podmiotów edukacji, ale również w czasoprzestrzeni magicznego oddziały wania dobrej wiary - illusio (Bourdieu 2006: 112). Owa iluzja jest przekonaniem, że narzucone tworzenie „wyczucia genderowej pozycji” w polu społecznym jest właściwe, niezbędne i korzystne dla uczennicy oraz ucznia - przyszłej obywatelki oraz przyszłego obywatela demokratycznego państwa. Praktyki komunikacyjne wyznaczają jednocześnie granice 
i parametry wiedzy, habitusów genderowych, nierówności szans edukacyjnych uczennic oraz uczniów. Proces konstruowania przedmiotu badań, jakim jest sposób utrwalania hierarchizacji genderowej w stylach komunikacyjnych podmiotów edukacji, oraz moje rozważania umiejscowione są w perspektywie strukturalnego konstruktywizmu.

Komunikowanie się w klasie szkolnej posiada specyficzne cechy, wynikające $\mathrm{z}$ autorytetu instytucji pedagogicznej oraz autorytetu poszczególnych pedagogów pracujących z uczennicami i uczniami w szkole podstawowej. Rekonstruując i analizując style komunikacyjne podmiotów edukacji, sprawdzam, czy można znaleźć w nich ślady sposobów urzeczywistniania się nauczycielskiej władzy. Moim prymarnym celem jest poznanie stylów komunikacyjnych, sposobu, w jaki ukazują one utrwalanie hierarchizacji genderowej w klasie szkolnej. Ponadto chcę pokazać, że jedna ze znaczących kategorii teorii społecznej Bourdieu, jaką stanowi illusio, jest bytem towarzyszącym i utrwalającym hierarchizację genderową w i poprzez style komunikacyjne podmiotów edukacji. Staram się jednocześnie odpowiedzieć na pytanie, jak wspomniana wyżej praktyczna wiara $\mathrm{w}$ to, że panujący porządek jest właściwy, oraz wpływ języka na utrwalanie panującego porządku wiążą się z refleksyjnością i pozycją jednostek w badanym polu. Patrząc na zróżnicowanie pozycji podmiotów, przeprowadzam analizę spójności pozycjonującego wpływu kodów Basila Bernsteina z utrwalaniem poprzez style komunikacyjne zhierarchizowanego oraz pozycjonującego jednostki porządku pola społecznego. W procesie socjalizacji uczennica i uczeń uczą się podporządkowywać swoje działania, myślenie oraz pragnienia kodowi językowemu, który nie tylko umożliwia i nakazuje pełnienie wyznaczonej roli w określony sposób, ale również wyznacza sposób myślenia i mówienia o niej. Pogłębiam analizę stylów komunikacyjnych za pomocą takich elementów teorii kodów językowych Bernsteina, jak: pozycjonowanie jednostek, role, wyznaczane granic między jednostkami oraz odtwarzanie kultury.

Język w użyciu jako ważny, zakorzeniony w codzienności, element pola społecznego, obok utrwalania wiedzy oraz zastanego porządku, służy również budowaniu przestrzeni do osiągania porozumienia. Dlatego przyglądam się także stylom komunikacyjnym pod kątem dyskursywnego wyodrębniania przestrzeni dla porozumienia zgodnie z logiką pola Bourdieu oraz sposobowi jego osiągania przez podmioty w polu klasy szkolnej.

$\mathrm{Z}$ determinacją podejmuję próbę urzeczywistnienia pogłębienia rozumienia problematyki języka w perspektywie gender, jak również budowania przestrzeni dla świadomości refleksyjnej nie tylko podmiotów edukacji w odniesieniu do procesów, które urzeczywistniają się w i poprzez relacje władzy, w aspekcie „gramatyki” dyskursywnej polityki genderowej. 
Nauczycielskie style komunikacyjne

Optyka lingwistyki Deborah Tannen w swoich ogólnych genderowych założeniach o dwóch odmiennościach, męskim i żeńskim sposobie komunikowania się, jest zgodna z logiką hierarchizacji genderowej w języku klasy szkolnej. Czytelne różnice w stylu komunikowania się mogą stwarzać zagrożenie dla dotychczas uznawanych norm funkcjonowania społecznego wraz ze społecznie akceptowanymi stereotypami oraz wzmocnieniami za ich odtwarzanie. Płeć kulturowa (gender) jest dynamicznym tworem oddziałującym na ścieranie się postaw a także sposobów widzenia jednostki oraz grupy, w której jest współtwórcą interakcji komunikacyjnych. Język klasy szkolnej stanowi wskaźnik ich zróżnicowania w stylach zarówno nauczycielek, nauczycieli, jak i uczennic oraz uczniów. Styl komunikowania się to kompetencja nie tylko merytoryczna i formalna zdolność do porozumiewania się, ale także zdolność do wyrażania postaw wobec uczestników procesu komunikacji na dwa sposoby. Genderlecty: żeński oraz męski wyznaczane są poprzez genderowe dystynkcje w mowie dziewcząt/kobiet oraz chłopców/mężczyzn. W omawianej teorii Tannen prymarne miejsce zajmuje kategoria, jaką jest różnica w zakresie kompetencji relacyjnej, która ujawnia się już w mowie dziecięcej, kształtującej się w grupach rówieśniczych. Grupy dziewczęce, zazwyczaj mało liczne, realizują zadanie nawiązywania i podtrzymywania więzi uczuciowych. Dziewczęta wzajemnie wspierają się oraz tworzą miłą atmosferę, a wynik inicjowanych przez nie gier kończy się remisem lub wynikiem zerowym (Tannen 1999). W skonfigurowanym w powyższy sposób klimacie komunikacyjnym utrwalane są schematy negocjowania oraz rozwiązywania ewentualnych konfliktów z konstruowaniem prostych i skutecznych kompromisów.

Natomiast bardziej liczne grupy chłopięce charakteryzują się strukturą hierarchiczną, w której dowodzącym zostaje ten, który wydaje polecenia oraz skutecznie nadzoruje ich wykonanie. Przywódca chłopięcej grupy uznawany jest za silnego, inteligentnego, konsekwentnego, wyróżniającego się poczuciem humoru kolegę. Założenia powyższej teorii wraz dyskursywnymi dystynkcjami genderowymi stanowią fundament, w oparciu o który można dokonać rekonstrukcji stylów komunikacyjnych oraz wyodrębnienia ich w płaszczyźnie porządkujących je typologii.

Leżący u podstaw teorii genderlectu algorytm dzielenia stylów komunikacyjnych na żeńskie i męskie stanowi tylko fundament dystynkcji genderowych. W tabeli 1 będącej zestawem typologii stylów komunikacyjnych zawarto dwa podstawowe style odnoszące się do teorii genderlectu, które zawierają po dwie klasy sposobów mówienia. Żeński styl komunikacyjny odnosi się do werbalnego komunikowania się nauczycielek oraz odrębnego stylu mówienia uczennic. Męski styl komunikacyjny natomiast obejmuje sposoby mówienia nauczycieli, a także styl uczniów. Zbyt „ciasny gorset” genderlectowej teorii skłonił mnie do skonstruowania nowej relacyjnej typologii I stylów komunikacyjnych podmiotów edukacji, 
pozwalającej uwydatnić oraz poddać bardzo szczegółowej analizie urzeczywistniające się $\mathrm{w}$ ich ramach praktyki komunikacyjne oraz fenomeny społeczne uwikłane w sieć relacyjnych powiązań.

Tabela 1. Zestawienie typologii zhierarchizowanych genderowo stylów komunikacyjnych podmiotów edukacji

\begin{tabular}{|c|c|c|c|}
\hline $\begin{array}{c}\text { Numer } \\
\text { typologii }\end{array}$ & $\begin{array}{l}\text { Typologia } \\
\text { (nazwa) }\end{array}$ & $\begin{array}{l}\text { Płaszczyzny relacyjne stylów } \\
\text { komunikacyjnych }\end{array}$ & Styl komunikacyjny \\
\hline 1. & $\begin{array}{l}\text { Teoria genderlect } \\
\text { (osnowa stylów } \\
\text { komunikacyj- } \\
\text { nych podmiotów } \\
\text { edukacji) }\end{array}$ & 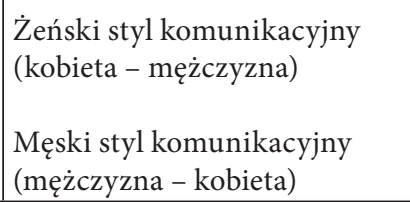 & $\begin{array}{l}\text { Styl komunikacyjny nauczycielek } \\
\text { Styl komunikacyjny uczennic } \\
\text { Styl komunikacyjny nauczycieli } \\
\text { Styl komunikacyjny uczniów }\end{array}$ \\
\hline 2. & $\begin{array}{l}\text { Typologia I } \\
\text { Typologia } \\
\text { relacyjna } \\
\text { (odnosi się do } \\
\text { teorii kodów } \\
\text { językowych } \\
\text { Bernsteina) }\end{array}$ & $\begin{array}{l}\text { Nauczycielka - uczennica, } \\
\text { nauczycielka - uczeń, nauczy- } \\
\text { ciel - uczennica, nauczyciel } \\
\text { - uczeń, } \\
\text { Uczennica - uczennica, uczeń } \\
\text { - uczeń, uczennica - uczeń, } \\
\text { uczeń-uczennica, } \\
\text { Uczennica - nauczycielka, } \\
\text { uczennica - nauczyciel, } \\
\text { uczeń - nauczycielka, uczeń } \\
\text { - nauczyciel }\end{array}$ & $\begin{array}{l}\text { Style komunikacyjne nauczy- } \\
\text { cielek i nauczycieli z uczenni- } \\
\text { cami i uczniami nie zawierają } \\
\text { elementu symetryczności. } \\
\text { Style komunikacyjne uczennic } \\
\text { i uczniów zawierają element } \\
\text { symetryczności. } \\
\text { Style komunikacyjne uczennic } \\
\text { i uczniów z nauczycielkami oraz } \\
\text { nauczycielami nie zawierają } \\
\text { elementu symetryczności. }\end{array}$ \\
\hline 3. & $\begin{array}{l}\text { Typologia II } \\
\text { Typologia nauczy- } \\
\text { cielskich stylów } \\
\text { komunikacyjnych }\end{array}$ & $\begin{array}{l}\text { Nauczycielskie style } \\
\text { komunikacyjne. } \\
\text { Typologia wyróżniona została } \\
\text { na podstawie kryterium wła- } \\
\text { dzy nauczycielki oraz nauczy- } \\
\text { ciela. Wszystkie powyższe } \\
\text { typologie dotyczą języka klasy } \\
\text { szkolnej uporządkowanego } \\
\text { zgodnie z polityką gender. }\end{array}$ & $\begin{array}{l}\text { Styl kontrolno-pozycjonująco- } \\
\text {-dyscyplinujacy (dalej: kpd) } \\
\text { Styl kpd z elementem nauczyciel- } \\
\text { skiego poczucia humoru } \\
\text { Dynamiczny styl komunikacji kpd } \\
\text { Styl kpd „młody badacz” } \\
\text { Styl subtelno-łagodny }\end{array}$ \\
\hline
\end{tabular}

Źródło: badania własne.

Owa sieć jawi się jako konstrukt koherentny oraz skonfigurowany z uwzględnieniem zhierarchizowanej genderowo relacji władzy i wiedzy. Bardzo czytelny jest sposób uprawianej przez pedagogów tradycyjnej dydaktyki odciskający swoje piętno na procesie konstruowania wiedzy oraz nadawania znaczeń. Słabym ogniwem wyżej opisanego systemu jest niski współczynnik językowej wrażliwości estetyczno-etycznej podmiotów w przestrzeni klasy szkolnej (Grzechnik 2015a). 
Omawianą typologię odniosłam do założeń teorii kodów językowych Bernsteina $\mathrm{w}$ aspekcie odtwarzania zhierarchizowanej genderowo kultury w przestrzeni komunikacyjnej klasy szkolnej (Bernstein 1975, 1990). Bernstein pokazywał, jak kody językowe determinowane są przez charakter podziału pracy i podstawowe wartości, które oddziałują na kulturę i system ról w głównych instytucjach socjalizujących, a zwłaszcza w rodzinie i szkole. Kulturowo uwarunkowany kod komunikacyjny uzależniony jest od pozycji jednostki i rodziny w strukturze klasowej. Moim zamiarem jest odniesienie stylów komunikacyjnych do kulturowo konstruowanego aspektu gender, aby dowiedzieć się, jak w klasie szkolnej aspekt gender wpływa na style komunikacyjne. Wyodrębnienie typologii I i typologii II ma również na celu znalezienie odpowiedzi na pytanie, w jaki sposób style komunikacyjne pozycjonują podmioty edukacji oraz w jaki sposób wpływają na pełnienie roli ucznia i roli uczennicy polu klasy szkolnej.

Kolejnym rodzajem typologii jest nowy w swojej konfiguracji konstrukt - typologia II, który odnosi się do grupy stylów mówienia nauczycielek i nauczycieli. Takie uporządkowanie zawiera sposoby widzenia stylów komunikacyjnych oraz zhierarchizowane genderowo działania komunikacyjne, omówione szczegółowo przy każdym $z$ analizowanych stylów. W gronie nauczycielskich sposobów mówienia znajdują się następujące style: kontrolno-pozycjonująco-dyscyplinujący (kpd), kontrolno-pozycjonująco-dyscyplinujący (kpd) z elementem nauczycielskiego poczucia humoru, dynamiczny styl komunikacji kpd, styl „młody badacz” oraz subtelno-łagodny, będący „odwrotnością” stylu kontrolno-pozycjonująco-dyscyplinującego (kpd).

\section{Nauczycielski styl kontrolująco-dyscyplinująco-pozycjonujący (kdp)}

W ramach stylu komunikacyjnego kdp nauczycielka i nauczyciel wydają zakazy, nakazy oraz swoiste stylistycznie polecenia co do zachowania się uczennic oraz uczniów w klasie szkolnej. Takie działania komunikacyjne wydają się mieć dla „kontrolujących” prymarne znaczenie. „Kontrolne nakazy” kierowane są do wychowanków w formie imperatywów lub pytań. Nauczyciel i nauczycielka nieustannie podkreślają intonacją, rytmem i akcentami towarzyszącymi omawianemu stylowi swoją pozycję w przestrzeni dyskursywnej, jednocześnie zarządzając wiedzą, sposobem jej „przyswajania” oraz emocjami (Galasiński 2008: 152, 153). Ponadto uplasowanie samej jednostki lekcyjnej jest znacznie wyższe niż prawa uczennicy i ucznia do odpowiadania na pytania nauczyciela w niczym oraz przez nikogo nieskrępowany sposób. W ramach tak skonfigurowanej logiki stylu kdp spontanicznie i swobodnie pojawiają się akty performatywne mające moc ranienia i jednocześnie podkreślania dominującej pozycji osoby dyscyplinującej oraz ustanawiającej młode podmioty (Kopciewicz: 2007, 2011). Do opisywanego stylu w ramach zarządzania sytuacjami mówienia przypisane są: pierwiastek krytyczności nauczycielskiej oraz 
wymuszanie milczenia i ciszy, które częściej zostają przyporządkowane uczennicom niż uczniom (Grzechnik 2015b). Reasumując powyższy sposób komunikowania, można powiedzieć, że ten dominujący w przestrzeni komunikacyjnej klasy szkolnej styl jest egzemplifikacją dominacji uwikłanej w nakazowo-zakazowo wiedzę, wzbogaconą mocą kontrolowania oraz performatywnego ranienia uczennic i uczniów.

N1H4: Czy mogłabyś się zająć sobą, bez komentarzy. (Uczeń U5 zaczął klaskać po słowach nauczyciela skierowanych do uczennicy Ua2).

N1H: Jeśli ktoś chce cokolwiek powiedzieć, podnosi rękę do góry.

U13: Mogli zabijać. (Uczeń U13 odpowiada po uprzednim podniesieniu ręki).

U16: Mogli. (Uczeń U16 odpowiada bez podniesienia ręki). [...] (lekcja historii nr 1)

Na7B: Chciałabym, żeby każdy z was tych pięć pierwiastków umiał wymienić, a nie takie tam mówienie, w sumie. [...] (lekcja przyrody $n r$ 1)

Na2P: Co wy sprawdzian napisaliście i się boicie, że was ta tablica napadnie, czy co? (lekcja języka polskiego nr 1)

N1H: Nie, bo kręgosłup ci się wygnie zupełnie niepotrzebnie.

U1: A mama mówi, że mam wygięty.

N1H: No, i to wcale nie jest fajne.

U5: Ty cały czas jesteś wygięty.

Ua2: Czy pogięty?

N1H: Czy mogłabyś się zająć sobą, bez komentarzy. (Uczeń U5 zaczął klaskać po słowach nauczyciela skierowanych do Ua2). (lekcja historii $n r 2$ )

Powyższy fragment wypowiedzi nauczycielki wskazuje na fakt, że pierwiastek krytyczności w interakcji pytań z odpowiedziami „inspiruje” nauczyciela do szybkiego udzielania odpowiedzi.

Ogromną potrzebę mówienia ma zdecydowana większość nauczycielek oraz nauczycieli. Jeśli chodzi o uczniów oraz uczennice nieco więcej uczniów niż uczennic stara się uzyskać pozwolenie na zabieranie głosu, natomiast zdecydowana większość chłopców z dużą determinacją stara się bardzo czytelnie zaistnieć w przestrzeni komunikacyjnej (Bochno 2009). Chłopcy, spotykając nauczycielskie

${ }^{4}$ Klucz oznaczeń badanych nauczycielek, nauczycieli, uczennic oraz uczniów - transkrypcje nagrań lekcji oraz dziennik obserwacji. Pomocniczo zastosowano pogrubienie oznaczenia w przypadku nauczycieli oraz nauczycielek: N1H - nauczyciel historii, Na2P - nauczycielka języka polskiego, Na3B - wychowawczyni 1, N4M - nauczyciel muzyki, Na5S - nauczycielka muzyki, N6R - nauczyciel religii, Na7B - nauczycielka przyrody, Na8 - wychowawczyni 2; Ua1, Ua2, Ua3, Ua4, Ua5, Ua6, Ua7, Ua8, Ua9, Ua10, Ua11, Ua12, Ua13, Ua14, Ua15, Ua16, Ua17, Ua18, Uax - uczennice; U1, U2, U3, U4, U5, U6, U7, U8, U9, U10, U11, U12, U13, U14, U15, U16, U17, U18, Ux - uczniowie. 
komunikacyjne utrudnienia, stanowczo walczą o „przynależną” im dyskursywną pozycję w klasie szkolnej. Komunikowanie się przez nauczycielki i nauczycieli w klasie szkolnej jest jakościowo różne z uczniami różnej płci (Kopciewicz 2007).

\section{Styl kontrolująco-dyscyplinująco-pozycjonujący z poczuciem humoru}

Odmianą tego stylu jest sposób nauczycielskiego komunikowania się z uczennicami i uczniami, który różni się od stylu kontrolująco-dyscyplinująco-pozycjonującego jednym drobnym elementem, jakim jest poczucie humoru czasem pozycjonujące wychowanków. Poczucie humoru w przestrzeni tego stylu ma prawo być urzeczywistnianie zarówno przez nauczycieli, jak i przez uczniów.

U16: Dziwne dźwięki.

N4M: Dlaczego? Ponieważ, kiedy się śmiejecie, to przepona intensywnie pracuje. Masuje wewnętrzne organy naszego ciała, co ma dobroczynny wpływ na cały organizm. Słucham.

U16: Jeżeli śmiech jest dla zdrowia, to pośmiejmy się grupowo.

N4M: No dobrze. Wszyscy głośno się śmieją. (Śmiech). Dobrze, dziękuję. Dziękuję. Zostawmy sobie trochę zdrowia na przerwę. (lekcja muzyki nr 3)

\section{„Dynamiczny” styl nauczycielski}

Sposób mówienia nauczycielki zaprezentowany w poniższym fragmencie charakteryzuje się, obok licznych nakazów, „narzucaniem tempa” i „szybko” zauważyć można, że połączenie dynamiki z częstym stosowaniem trybu warunkowego konstruuje stylistyczną swoistość wypowiadanych aktów mowy. Kategoria ta odnosi się w analizowanym przypadku do „potocznej” wypowiedzi, która oferuje słuchaczkom oraz słuchaczom zimną i niezbyt miłą intonację wzmacnianą niespecyficznym rozmieszczeniem akcentów. Poniższy kilkuminutowy fragment dialogu ma moc unicestwiania w dyskursie klasy szkolnej przestrzeni dla interakcji pytań z odpowiedziami:

Na7B: Szybciutko. OU14 może ma coś do powiedzenia. Obudźcie się ludzie!

Na7B: Przemiany fizyczne i chemiczne. Tempo szybkie.

Ua6: Ooo.

Na7B: Czy ja prosiłam o marudzenie? Chyba, że ktoś omawia. Zamiast sobie powtórzyć w czasie wolnym, to wy dyskutujecie.

U16: A jaki temat mamy?

Na7B: Radzę sobie powtórzyć.

Ua6: A mnie nie było, to jak mam powtórzyć? [...] 
Na7B: Hej! Koniec marudzenia. Bierzemy się do pracy. Uwaga! [...] Jedna osoba odpowiada, a potem szybko pytamy. Proszę to może Ua6.

Ua6: Ale mnie nie było.

Na7B: Ale. A kiedy ty wróciłaś do szkoły? Dzisiaj?

Ua6: No, nie. Ale na tym mnie nie było właśnie. [...] Bo ja mam ten temat, ale się go nie nauczyłam. [...]

Na7B: Dobrze. Dzisiaj jest minus, a na następną lekcję, jak nie będziesz umiała, dostaniesz jedynkę. [...] Proszę, po pierwsze szybko, raz, dwa. A wy do tej pory zamiast powtórzyć, to siedzicie, jak takie sroki!

Ua6: A proszę pani. To, to świat materii?

Na7B: Tak.

Ua6: To byłam.

Na7B: Jeszcze nie zdążyłam ci tego minusa wstawić, szybko!

Ua6: Czyli materia.

Na7B: Proszę pytanie jeszcze do niej. Szybko, raz, dwa! [...] Narzucamy tempo!

Na7B: Jeżeli będziecie się guzdrali w miarę szybko, to może dam troszeczkę czasu, żeby zrobić jakieś doświadczenie. Jeżeli będziecie mieli tempo beznadziejne, to doświadczenia nie będzie [...].

Na7B: [...] Narzucamy tempo, bo mamy jeszcze doświadczenie.

Na7B: Krzepnięcie. [...] Proszę drugi punkt. Proszę, kto pisze? Proszę.

Ua10: Ja. (Uczennica jednocześnie podnosi rękę do góry).

Na7B: Ruszaj się, no! [...]

Na7B: Proszę. Możecie się nie drzeć? (do chłopców). Posuń się. (lekcja przyrody nr 2)

W przestrzeni omawianego nauczycielskiego stylu uczennice odpowiadają nieśmiało, cichym głosem. Ponadto mówią rzadko, gdyż niezbyt często zapraszane są do zabierania głosu. Kiedy już uczennica otrzyma nakaz zabrania głosu, zobowiązana jest udzielać odpowiedzi na dość pokaźny strumień nauczycielskich pytań, czego przykładem jest wyżej zaprezentowany fragment.

Nauczycielka Na2P posiadająca wyrazistą przewagę komunikacyjną mówi dużo i głośno, współtworząc z dziewczynkami oraz chłopcami czytelną dynamikę stylu komunikacyjnego, czego przykładem jest poniższy fragment.

U16: Ale chcesz, żeby szybko?

Na2P: Ruszaj się, no! Słuchajcie, szybciej, bo was tutaj naprawdę Wielkanoc zastanie.

U14: Jutro jest Wielkanoc? (lekcja języka polskiego nr 3)

„Szara” codzienność klasy szkolnej przeplatana z tworzeniem genderowych podziałów to kategoria manifestująca się interaktywnie oraz bardzo czytelnie w prezentowanych fragmentach "gier językowych”. Owe podziały zarysowały się między innymi w tendencji do zaniżania ocen za wypowiedź uczennicy.

Na7B: Proszę, jak oceniacie koleżankę?

U16, U12: Pięć. 
Na7B: O nie, panowie, co najwyżej cztery.

U16: Pięć!

Na7B: Powiedziałam! (Głośno i dobitnie) Daj mi zeszyt, szybko! (lekcja przyrody nr 2)

Uczennice i uczniowie dostali pozwolenie/polecenie ocenienia wypowiedzi koleżanki: „Proszę, jak oceniacie koleżankę?” Koledzy ocenili tę wypowiedź na "pięć”. Nauczycielka postanowiła obdarować uczennicę oceną „dobry”, a po powtórnym wystąpieniu kolegów „z prośbą” o ocenę bardzo dobrą „oceniająca” zaprotestowała głośno i stanowczo: „Powiedziałam!”. Nauczycielka zarządza sytuacjami mówienia, decyduje o logice oceniania wypowiedzi uczennic i uczniów oraz o trybie sankcjonowania za brak uczniowskiej subordynacji.

\section{Styl kontrolująco-dyscyplinująco-pozycjonujący - „młody badacz”}

W materiale empirycznym wyodrębniono kolejny styl komunikacyjny, jakim jest styl kpd-„,młody badacz”, stanowiący mieszankę stylu kdp ze stylem zorientowanym na „młodego badacza” (w mniejszym stopniu na „badaczkę”) otaczającego świata. Nauczyciel w ramach takiego sposobu mówienia oraz komunikowania się z uczniem rozbudza jego ciekawość oraz wrażliwość poznawczą, która łączy się tylko częściowo ze swobodną spontanicznością uczniowskiego eksplorowania rzeczywistości. Omawiany sposób komunikowania zawiera zdecydowanie więcej pierwiastka „kpd” niż „młodego badacza”. Jest to jedyny styl mówienia nauczycielek oraz nauczycieli, który dopuszcza aspekt eksploracyjności w myśleniu oraz mówieniu w procesie konstruowania wiedzy przez uczniów i bardzo rzadko przez uczennice (Grzechnik 2014).

N4M: Nie wiem, czy wiecie, ale w czasach średniowiecza była tortura, kara, polegająca na wyrywaniu języka.

U16: Wyrywali?

N4M: Tak, wyrywali język za karę skazańcom. Tobie też chyba bym dzisiaj to zrobił.

U1: Aaa, mnie?

U10: Tobie by się przydało. (lekcja muzyki nr 3)

We wszystkich omawianych powyżej czterech nauczycielskich stylach komunikacyjnych swoje zarezerwowane miejsce zajmuje werbalna, czytelna, często raniąca, pozycjonująca i ujarzmiająca, kierowana wprost kategoria zwana w niniejszym projekcie performatywną bezpośredniością nauczycielską. Stanowi ona swoistą odmianę „pedagogicznej sztuki performatywnej”, o której należy mówić oraz pisać. Nie znaleziono natomiast owej bezpośredniości w poniższym, tak bardzo odbiegającym od pozostałych, wyśmiewanym przez uczniów stylu. 


\section{Subtelno-łagodny styl komunikacyjny}

Ostatnim zauważonym i zrekonstruowanym stylem mówienia jest styl subtelno-łagodny uznający oraz respektujący poszanowanie godności drugiego człowieka, każdej dziewczynki i każdego chłopca. Styl ten uplasowany w typologii II stylów nauczycielskich nie spotkał się z aprobatą uczniów (chłopców). Jego entuzjastkami są tylko dziewczęta, które w pełni akceptują zajmowane pozycje w przestrzeni dyskursywnej zgodne z założeniami teorii społecznej Bourdieu. Proces uczenia się spokojnych uczennic zakłócany jest przez głośne oraz destrukcyjnie wpływające na przebieg lekcji zachowanie chłopców. Wrażliwa, spokojna, zrównoważona, taktowna, cierpliwa, dbająca o kulturę słowa oraz otwarta na uczennice oraz uczniów nauczycielka ma trudności z utrzymaniem dyscypliny w dyskursywnej przestrzeni klasy szkolnej. Jej styl komunikacyjny ukazuje, że osoba ta jest prawie ideałem nauczycielki otwartej, cierpliwej, charakteryzującej się wysokimi kompetencjami budowania interakcji komunikacyjnej z uwzględnieniem jej etyczno-estetycznego aspektu.

Każdy z powyższych stylów zawiera elementy indywidualności nauczyciela, które przekładają się na swoistość stylistyczną wypowiedzi, różną w każdym stylu komunikacyjnym nauczyciela oraz nauczycielki.

Na2P: U3! Jest za głośno. Czy wy przestaniecie gadać?

Na2P: Co się dzieje? Taka cisza. Myślę, że trzeba by było tak nagrywać, co lekcję, widzę. (lekcja języka polskiego $\mathrm{nr}$ 2)

Powyższe fragmenty wypowiedzi nauczyciela oraz nauczycielki stanowią sugestię, że obecność kamery wpisuje się w logikę podstawowego komunikacyjnego stylu nauczycielskiego, którego głównym zadaniem jest pozycjonować, kontrolować oraz dyscyplinować wychowanków.

Ua5: Czemu?

Na2P: Jeśli chodzi o ciszę i spokój. Napisane? (lekcja języka polskiego nr 4)

N1H: Dzieci już zamykają buzię. Będziecie mieli teraz okazję się wygadać.

N1H: Marysiu, przepisujesz z tablicy! (Uczennica Ua3 potakuje posłusznie kilkukrotnym ruchem głowy.)

N1H: (Do Ua12) Zaraz ciebie przesadzę na stałe. (lekcja historii nr 4)

Na2P: Ua7! Na jaki temat ty jeszcze dyskutujesz?

Ua7: On się mnie pyta, co to jest? Kwiaty.

Na2P: A ty nie gadasz, w tym samym momencie? (lekcja jezzyka polskiego $n \mathrm{r}$ 2) 
Uczennica Ua5, choć ośmieliła się zadać pytanie, mówi szeptem, cicho, niepewnie, niewyraźnie. Posiadająca mało pewności siebie Uczennica Ua7 jest spokojną, osiągającą bardzo dobre wyniki w nauce dziewczyną, która mówi cicho i nieśmiało.

Sposób skonstruowania oraz opisania wyodrębnionych typologii pozwala na pogłębioną analizę i interpretację utrwalania $\mathrm{w}$ praktykach komunikacyjnych podmiotów edukacji zjawiska hierarchizacji genderowej w klasie szkolnej.

W stylu mówienia uczennic oraz uczniów zarówno w klasie, jak i na szkolnym korytarzu daje się słyszeć „wołanie” uczennic oraz uczniów o symetryczność w nauczycielsko-uczniowskim komunikowaniu się, a w jej ramach o większą atencję, otwartość na młode umysły oraz językową wrażliwość etyczno-estetyczną. Aspekt gender stylów komunikacyjnych wraz z illusio przenosi się poza klasę szkolną. Moc języka podmiotów edukacji towarzyszyć będzie prawdopodobnie uczennicom oraz uczniom w przyszłości (Marody 1982).

Obserwując $w$ ramach etnografii komunikacji sposoby komunikowania się podmiotów w klasie szkolnej, odnosiłam wrażenie, że działanie językowe konstruowane oraz wygłaszane przez nadawcę - nauczycielkę/nauczyciela - urzeczywistniało się mechanicznie i nieświadomie. Jednakże nieświadomość, czy też niska świadomość, wzmacniania nieustannie przez illusio, stanowi gwarancję wielu kolejnych powtórzeń oraz odczytań jako prawidłowe, właściwe i konieczne. Ten „swoisty sposób działania komunikacyjnego" powiązany jest nie tylko z aktami mowy, ale również z performatywami (Butler 2010). Ich umiejscowienie w stylach komunikacyjnych jest zgodne z zasadami działania pola społecznego (klasy szkolnej), które służą utrwalaniu hierarchizacji genderowej, ujarzmianiu poznania, które odbiera nie tylko uczennicy, ale również uczniowi „wolność” w procesie tworzenia wiedzy i codziennie wyznacza granice zakorzeniania się w codziennie poznawanych i odtwarzanych światach.

Zauważyć można, że omawiane na podstawie bogatego materiału empirycznego style są odmianą stylu potocznego, gdyż cechują się bogactwem wyróżniających cech, do których należą: ustna droga przekazu językowego, nasilona ekspresywność i impresywność zaopatrzone w elipsy, równoważniki i wykrzyknienia, a także wysoki stopień zmienności składników, jakimi są kontrasty kulturowej powagi oraz poczucia humoru splecionego $z$ kontrolą i ujarzmianiem podmiotu. Kolejnym argumentem na „szkolną potoczność” (Klus-Stańska 2010) owego sposobu mówienia jest stałe nastawienie na szybki kontakt językowy oraz związane z tym posługiwanie się szablonami, stereotypami (formułami) frazeologicznymi, składniowymi i sytuacyjnymi. Niebagatelne znaczenie dla całego klimatu analizy oraz interpretacji stylów komunikacji ma brak występowania w aktach mowy nauczycielek i nauczycieli wypracowanej składni w oparciu o bogatą terminologię specjalną, związaną z opisem otaczającej rzeczywistości, którą konstruują podmioty edukacji. Obok „szkolnej potoczności” pojawiła się również oficjalna szkolna, na wskroś normatywna forma przekazu wiedzy sprzężona ze schematyzmem, 
nienaruszalnością językowego illusio oraz mechanizmów rządzących polem dyskursu. Zgodna z panującym hierarchicznym porządkiem w szkole wiedza spleciona jest ściśle $\mathrm{z}$ impresywną funkcją języka nakłaniającą uczennice i uczniów do podejmowania takich działań oraz prezentowaniu takich postaw, jakich oczekują nauczycielka i nauczyciel. Zarządzający sytuacjami mówienia nauczycielka i nauczyciel są dobrze zorientowani w tym, czego potrzebują uczniowie, lub przynajmniej są przekonani o tym oraz wierzą, że tak w istocie jest.

\section{Podsumowanie}

Realizując swój projekt badawczy, podjęłam próbę odpowiedzi na pytanie, czy mogę potwierdzić rezultaty prowadzonych wcześniej przez innych naukowców badań, czy też pokazać, że dyskursywne genderowe umiejscowienie uczennic i uczennic $\mathrm{w}$ badanej przeze mnie klasie szkolnej nie istnieje.

W zakończeniu niniejszego artykułu chciałabym umieścić trzy zasadnicze wnioski. Po pierwsze można z całą stanowczością stwierdzić, że w procesie nauczania i uczenia się w nauczycielsko-uczniowskich stylach komunikacyjnych będących zbiorem działań utrwalane jest zjawisko hierarchizacji genderowej. Pole społeczne, jakie stanowi klasa szkolna, to przestrzeń, w której tworzona jest wiedza połączona z nauczycielską władzą utrwalającą polaryzację genderową uczennic oraz uczniów. Wiedza dostarczana jest w „najlepszy i szczególny” zarazem sposób, zatem stereotypowo, naiwnie oraz tradycyjnie. Siłą napędową, a zarazem sprawczą tejże hierarchizacji jest sprzężony z utrwalającą mocą illusio efekt mnożnikowy ${ }^{5}$ potencjału zbioru wszystkich cech nauczycielskich stylów komunikacyjnych. Uprawomocnieniem dla owych „tradycyjnych” stylów komunikacyjnych jest nie tylko nauczycielska i wszechobecna władza (Foucault 2002, 2010), ale również umiejscowienie i charakter nasyconej „genderową potocznością” wiedzy wraz z bardzo poważną rolą, jaką przyszło jej odgrywać w szkole.

Po drugie style komunikacyjne konstruowane przez nauczycielki i nauczyciela kierowane do ucznia oraz uczennicy pozycjonują każdy podmiot edukacji w klasie szkolnej w odmienny sposób. Istnieje duże prawdopodobieństwo, że język, style komunikacyjne uczennic, uczniów, nauczycieli oraz nauczycielek przejawiające się jako utrwalanie różnic genderowych skutecznie wpływają na konstruowanie „uporządkowanych możliwości” oraz wybór „oczywistych” pozycji dziewcząt oraz chłopców w szeroko pojętym polu społecznym w przyszłości.

Kończąc podsumowanie, chciałabym podkreślić, że wyniki przeprowadzonych przeze mnie badań pokazują, że szkolne interakcje werbalne są egzemplifikacją zbioru przyczyn braku oraz niweczenia szansy na konsensus. Zdzisław Aleksander

\footnotetext{
${ }^{5}$ Kategoria zapośredniczona z języka ekonomii, charakteryzująca potęgowanie się i wzmacnianie siły poprzez scalenie poszczególnych czynników.
} 
w jednym ze swych dzieł opisuje szansę na międzypokoleniowy dialog współczesnych podmiotów edukacyjnych dotyczący uczennic i uczniów w wieku 15 lat (Aleksander 2009), dla której w świetle moich badań w odniesieniu do 12-letnich dziewcząt oraz chłopców niewiele jest miejsca w szkole. Na podstawie moich badań etnograficznych można zauważyć omawianą wyżej szansę, jednakże sposób, w jaki komunikują się podmioty edukacji, nie przyczynia się znacząco do konstruowania przestrzeni umożliwiającej jej rozwój i uzyskanie silnej pozycji w polu klasy szkolnej. W tle spolaryzowanych genderowo stylów komunikacyjnych umiejscowionych w dyskursywnej przestrzeni klasy szkolnej urzeczywistnia się fenomen braku językowej wrażliwości etyczno-estetycznej, zaufania, niezadawalająca jakość relacji nauczycielsko-uczniowskich oraz zniechęcenie. Na podstawie powyższej prawdy można wysnuć wniosek, że zrozumienie oraz porozumienie pomiędzy podmiotami edukacji wydaje się niemożliwe.

\section{Literatura}

Aleksander Z., 2009, Szansa na międzypokoleniowy dialog w kontekście rozumienia słów z zakresu moralności przez współczesne podmioty edukacyjne, Gdańsk: Wydawnictwo Uniwersytetu Gdańskiego.

Bernstein B., 1990, Odtwarzanie kultury, tłum. Z. Bokszański, A. Piotrowski, Warszawa: Państwowy Instytut Wydawniczy.

Bernstein B., 1975, Class, Code and Control, Toward a Theory of Educational Tramsmissions, Vol. 3, London-Boston: \& Kegan Paul.

Bochno E., 2009, Stereotyp płci czy płeć języka? Szkolne interakcje komunikacyjne nauczyciela z uczennicami [w:] Koniec mitu niewinności. Płeć i seksualność w socjalizacji edukacji, red. L. Kopciewicz, E. Zierkiewicz, Warszawa: Wydawnictwo Psychologii i Kultury ENETEIA.

Bourdieu P., 2005, Dystynkcja. Społeczna krytyka władzy sądzenia, tłum. P. Biłos, Warszawa: Wydawnictwo Naukowe Scholar.

Butler J., 2010, Walczace słowa i polityka performatywu, tłum. A. Ostolski, Warszawa: Wydawnictwo Krytyki Politycznej.

Foucault M., 2002, Słowa i rzeczy. Archeologia nauk humanistycznych, tłum. T. Komendant, Gdańsk: Słowo/obraz terytoria.

Foucault M., 2010, Bezpieczeństwo, terytorium, populacja, tłum. M. Herer, Warszawa: Wydawnictwo Naukowe PWN.

Galasiński D., 2008, Man and the Language of Emotion, New York: Palgrave Macmillan.

Grzechnik S., 2014, Dyskursywne konstruowanie wiedzy zgodnie z logika budowania męskiego habitusu uczniów w klasie szkolnej, "Ars Educandi” t. 11, red. H. Bougsiaa, L. Kopciewicz, M. Welenc.

Grzechnik S., 2015a, Pozycja aktów performatywnych oraz językowej wrażliwości etycznej $w$ zhierarchizowanym rodzajowo-dyskursywnym polu klasy szkolnej. Krytyczna analiza dyskursu [w:] Codzienność, performatywność, demokracja. Pedagogika wobec 
norm życiowych i problematyki nienormatywności, red. L. Kopciewicz, B. Simlat-Żuk, Gdańsk: Wydawnictwo Naukowe KATEDRA.

Grzechnik S., 2015b, Sprawstwo praktyk komunikacyjnych a kształtowanie się męskiego habitusu w klasie szkolnej. Krytyczna analiza dyskursu, „Wymiary męskości” nr 10.

Karwatowska M., Szpyra-Kozłowska J., 2005, Lingwistyka płci. Ona i on w języku polskim, Lublin: Wydawnictwo Uniwersytetu Marii Curie-Skłodowskiej.

Klus-Stańska D., 2010, Dydaktyka wobec chaosu pojęć i zdarzeń, Warszawa: Wydawnictwo Akademickie Żak.

Klus-Stańska D., 2012, Konstruowanie wiedzy w szkole, Olsztyn: Wydawnictwo Uniwersytetu Warmińsko-Mazurskiego.

Kopciewicz. L., 2007, Rodzaj i edukacja. Studium fenomenograficzne z zastosowaniem teorii społecznej Pierre’a Bourdieu, Wrocław: Wydawnictwo Naukowe Dolnośląskiej Szkoły Wyższej Edukacji TWP.

Kopciewicz L., 2011, Nauczycielskie poniżanie. Szkolna przemoc wobec dziewcząt, Warszawa: Wydawnictwo Difin.

Marody M., 1982, Język i wiedza potoczna w wyjaśnianiu zachowań, „Studia Socjologiczne” nr 3-4.

Tannen D., 1999, Ty nic nie rozumiesz! Kobieta i mężczyzna w rozmowie, tłum. A. Sylwanowicz, Poznań: Wydawnictwo W.A.B..

\begin{abstract}
Abstrakt
Komunikowanie się jest procesem społecznym nieodłącznie związanym z procesem nauczania i uczenia się uczennic oraz uczniów. Style komunikacyjne nauczycielek oraz nauczycieli ujawniają androcentryzm w postaci genderowych nierówności wpisanych w logikę funkcjonowania pola społecznego, jakim jest klasa szkolna. W niniejszym artykule prezentuję style komunikacyjne urzeczywistniane przez nauczycielki i nauczycieli $\mathrm{w}$ interakcjach werbalnych $\mathrm{z}$ uczennicami oraz uczniami. Interakcje komunikacyjne są zhierarchizowane genderowo, co oznacza, że dziewczęta umiejscowione są w innych punktach badanego pola niż chłopcy. Wiąże się to z faktem, że w dyskursywnej przestrzeni klasy szkolnej tworzona jest spolaryzowana genderowo wiedza. Spleciona jest ona z nauczycielską władzą przy współudziale mocy „tradycyjnego” illusio, stanowiącego uprawomocnienie dla stosowanych stylów komunikacyjnych. Sposób użycia języka przez nauczycielki i nauczycieli odkrywa fenomen braku językowej wrażliwości etyczno-estetycznej oraz jakość relacji nauczycielsko-uczniowskich przyczyniających się do braku porozumienia pomiędzy podmiotami edukacji.
\end{abstract}

\title{
Słowa kluczowe
}

hierarchizacja genderowa/nierówności, style komunikacyjne, porozumienie, szkoła 


\section{Summary}

Communication styles of education entities in gender perspective. Critical discourse analysis

This article is on exploration of the communication styles of teachers in classroom in gender perspective. The ways of speaking show how power and knowledge are constructed by verbal interactions. Schoolchildren have to be positioned in traditional order in discursive space of school. The first is teacher, the second - boys, and then - girls. Quality of communication styles do not contribute to reach a consensus between teachers, schoolgirls and schoolboys.

\section{Keywords}

gender hierarchization/inequality, communications styles, consensus, school 